\title{
Efforts to Prevent FFB Theft in Plantation SOEs through Optimizing CSR Funds by Involving the Police
}

\author{
Alimuddin Sinurat ${ }^{1}$, Budiman Ginting $^{2}$, Ediwarman $^{3}$, Mahmud Mulyadi $^{4}$ \\ \{alimsinurat@gmail.com $\left.{ }^{1}\right\}$ \\ Universitas Sumatera Utara, Indonesia ${ }^{1,2,3,4}$
}

\begin{abstract}
The main objective of establishing a Plantation BUMN, especially for the production of palm oil, is to obtain economic benefits and state revenues to realize public benefits. One of the factors that cause state-owned plantation companies to suffer losses is because of the rampant palm theft. This study discusses the problem of palm oil theft in state-owned plantations in terms of prevention through optimizing CSR funds by involving the role of the National Police. The urgency of efforts to prevent palm oil theft by involving Babinkamtibmas, Ditpamobvit, and Korsabhara is carried out to focus on pre-emptive and preventive efforts. This research method is normative juridical and qualitative analysis. The results of the study found that the increasing number of cases of palm oil theft in stateowned plantations caused economic losses for companies, investors, and the state. It was concluded that efforts to prevent palm theft in state-owned plantations through optimizing CSR funds by involving the assistance of the National Police were very effective in reducing or at least reducing the rate of palm theft, which in turn could increase the value of palm fruit production, increase company revenues and state revenues from plantation products. So that the state's goal of establishing Plantation SOEs is maximally achieved in the context of implementing public benefits such as fulfilling the needs of many people. It is hoped that the State-Owned Enterprises Plantation will form a partnership with the National Police by focusing on pre-emptive and preventive measures to prevent and reduce palm oil theft by the CSR mandate in the Company Law.
\end{abstract}

Keywords: Theft, State-Owned Enterprises, Plantations, Police, CSR

\section{Introduction}

The purpose of the Republic of Indonesia to establish a State-Owned Enterprise in the Plantation sector (BUMN Plantation) is to obtain economic benefits and state revenues; public benefit as the fulfillment of the needs of many people; actively participate in guiding and assisting entrepreneurs from economically weak groups, cooperatives, and the community; as well as pioneering business activities that have not been implemented by the private sector [1].

Plantation SOEs are engaged in palm oil commodities, namely the Nusantara Plantation Limited Company (PTPN), which is part of the total number of SOEs in Indonesia which currently number 114 companies [2]. All state-owned plantation companies from PTPN I to PTPN XIV under the leadership of PTPN III as a Holding Company since 2014 [3]. All subsidiaries form a single commercial entity [4].

Currently, the state share through direct investment in PTPN IV is only 10\%, not up to $51 \%$ because PTPN IV has become a subsidiary of the "holding company" PT. Perkebunan Nusantara III (Persero). The abolition of the status is carried out by transferring state-owned shares in 
PTPN IV to PTPN III as the parent of the plantation BUMN. The legal basis for the establishment of a BUMN holding is stated in Government Regulation No. 72 of 2016 concerning Amendments to Government Regulation No. 44 of 2005 concerning Procedures for State Capital Participation and Administration in State-Owned Enterprises and Limited Liability Companies ${ }^{1}$.

Based on the facts, there are still many palm oil thefts in state-owned plantations that can harm the company and the state. This issue has attracted stakeholders' attention to how weak efforts to prevent palm oil theft are. Outsiders are no exception, company insiders are also involved, almost every day in places that are still within the plantations belonging to PTPN II, PTPN III, and PTPN IV.

In cases of palm oil theft within the state-owned plantation companies are not prevented optimally, the state plantation companies will continue to experience large economic losses. In the end, the achievement of the goals of its establishment will also be disrupted because the results achieved will decline and will inevitably affect the state's efforts to provide public benefits and the welfare of the people.

One of the efforts to prevent palm theft in state-owned plantations is to optimize the use of Corporate Social Responsibility (CSR) funds. The purpose of prevention is carried out by focusing on pre-emptive and preventive efforts by involving the role of the Indonesian National Police (Polri), especially the Community Order Supervisory Unit (Babinkamtibmas), the Directorate for Security of Vital Objects (Ditpamobvit) of the Samapta Bhayangkara Corps (Korsabhara). For pre-emptive purposes, Plantation SOEs can ask for help and cooperate with Babinkamtibmas, while for prevention they can ask Dirpamobvit and Sabhara for assistance.

\section{Method}

This type of research method is normative juridical with qualitative analysis. Analyzing the primary legal material in Law No. 40 No. 2007 concerning Limited Liability Companies and Law No. 19 of 2003 concerning BUMN which regulates CSR about the duties and functions of the Police in the field of prevention as regulated in Law No. 2 of 2002 concerning the Police. From the legal material, it will be investigated the implementation of the duties and functions of the Police in the Plantation BUMN environment to prevent the theft of palm oil.

\section{Results and Discussion}

\subsection{Stakeholder Theory}

According to John Elkington in "Cannibal with Forks: The Triple Bottom Line of Twentieth Century Business" (1997), says that:

"if a company wants to remain sustainable, then it needs to pay attention not only to the interests of shareholders (profit), but also to pay attention to the welfare of the

\footnotetext{
${ }^{1}$ The legal basis for the establishment of a BUMN holding is stated in Government Regulation no. 72 of 2016 concerning Amendments to Government Regulation No. 44 of 2005 concerning Procedures for State Capital Participation and Administration in State-Owned Enterprises and Limited Liability Companies.
} 
shareholders. the people in it and around it (people) and the preservation of the environment (planet)" [5].

Stakeholder theory states that the basic obligation of management is not to maximize the financial success of the company, but to ensure its survival by balancing the conflicting demands of various stakeholders. Companies must be managed for the benefit of stakeholders, customers, suppliers, owners, employees, and local communities. The rights of these groups must be ensured and, furthermore, the groups must participate, in some sense, in decisions that substantially affect their well-being.

Thus, stakeholder theory or stakeholder primacy influences the law in the corporate sector to direct the management of the corporation to the interests of the stakeholders. Stakeholder theory that influences law in the field of corporations is because, the theory of "a stakeholder theory of the modern corporation" believes that modern corporations have an obligation to ensure their survival by balancing the conflicting demands of various stakeholders. These stakeholders consist of: stakeholders, customers, suppliers, owners, employees, and local communities.

Corporations that aim to ensure their survival by balancing the demands of these stakeholders must be managed with Good Corporate Governance (GCG). This is because, according to the Forum for Corporate Governance in Indonesia (2001), it states that GCG is a set of regulations that stipulate the relationship between management stakeholders, creditors, the government, employees, and other internal and external stakeholders about their rights and obligations. them, or in other words the system that directs and controls the company [6].

Good Corporate Governance is a healthy corporate governance procedure that has been introduced by the Indonesian government and the International Monetary Fund (IMF) [7]. According to The Indonesian Institute for Corporate Governance (IICG), Corporate Governance is a series of mechanisms that direct and control a company so that the company's operations are run by the expectations of stakeholders [8].

Corporate Governance is a series of structured processes used to manage and direct or lead business and corporate endeavors to increase corporate values and business continuity. Good corporate governance is a structure, system, and process used by company organs as an effort to provide added value to the company in a sustainable manner in the long term, while taking into account the interests of other stakeholders, based on morals, ethics, culture, and other applicable rules.

The term good corporate governance emerged in the late 1980s which was introduced by the Cadbury Committee in a report known as the Cadbury Report [9]. The word governance is defined as the activity or manner of governing, while the meaning of governance is having the power or right to govern [10].

Good corporate governance is defined as a company that has been managed properly and correctly and is based on the principles of fairness, accountability, responsibility, transparency. With this principle, the value of the company in the long term will increase without ignoring the interests of other stakeholders. The implementation of the principles of good corporate governance is an important step in building and restoring public trust in the company [11].

The relationship between stakeholder theory and this research is that the implementation of good corporate governance (GCG) in state-owned plantations is not solely for the benefit of the company owner (in State), but for the public interest, namely all stakeholders, especially the community around coconut plantations. palm oil owned by the State-Owned Plantation. 


\subsection{Cases of Palm Theft in Plantation of SOE's}

The following several cases of palm oil theft also show the amount of loss, but if not handled or prevented can cause considerable losses and have an impact on company and state revenues. This is because palm theft is carried out continuously, even almost every day in several plantations belonging to PTPN II, PTPN III, and PTPN IV.

\begin{tabular}{|c|c|c|c|}
\hline No. & Location & Loss & Jurisdiction \\
\hline 1. & Desa Manunggal, Helvetia. & $\begin{array}{c}4 \text { ton palm } \\
\text { (Rp. } 8.000 .000)\end{array}$ & Polres Belawan \\
\hline 2. & $\begin{array}{l}\text { Kebun Tanjung Jati, Blok K, Afedling } \\
\text { X. }\end{array}$ & $\begin{array}{c}10 \mathrm{TBS} \\
\text { (Rp. } 600.000) \\
\end{array}$ & Polres Binjai \\
\hline 3. & $\begin{array}{l}\text { Afdeling I, Blok V, Tanjung Mulia, } \\
\text { Pagar Merbau, Deli Serdang. }\end{array}$ & $\begin{array}{c}600 \mathrm{TBS} \\
\text { (Rp. } 750.000 .000)\end{array}$ & $\begin{array}{l}\text { Polres Deli } \\
\text { Serdang }\end{array}$ \\
\hline 4. & $\begin{array}{l}\text { Desa Tanjung Putus, Padang Tualang, } \\
\text { Langkat. }\end{array}$ & $2 \mathrm{TBS}$ & Polres Langkat \\
\hline 5. & Perbaungan & $\begin{array}{c}4 \text { TBS } \\
\text { (Rp. 120.000) }\end{array}$ & $\begin{array}{c}\text { Polsek } \\
\text { Perbaungan }\end{array}$ \\
\hline 6. & $\begin{array}{l}\text { Areal Afd III Blok 11, Batang Serangan, } \\
\text { Tebing Tanjung Selamat, Padang } \\
\text { Tualang, Langkat. }\end{array}$ & $40 \mathrm{~kg}$ & Polres Langkat \\
\hline
\end{tabular}

Fig. 1. Palm Theft in PTPN II (Source: PTPN II).

\begin{tabular}{|c|c|c|c|}
\hline No. & $\begin{array}{r}\text { Location } \\
\end{array}$ & Loss & Jurisdiction \\
\hline 1. & Afdeling II Blok A 3 TM 2004 & 2 TBS & Polres Labura \\
\hline 2. & $\begin{array}{l}\text { Desa Nagori Sei Mangkei, Bosar Maligas, } \\
\text { Simalungun. }\end{array}$ & $\begin{array}{l}500 \mathrm{~kg}, 11 \text { sack, } \\
\text { and } 67 \text { TBS }\end{array}$ & $\begin{array}{c}\text { Polres } \\
\text { Simalungun }\end{array}$ \\
\hline 3. & $\begin{array}{l}\text { Kanas Afdeling 9, Bilah Hulu, Labuhan } \\
\text { Batu. }\end{array}$ & 10 ton/day & $\begin{array}{l}\text { Polres Labuhan } \\
\text { Batu } \\
\end{array}$ \\
\hline 4. & $\begin{array}{l}\text { Kanas Afdeling 3, Bilah Hulu, Labuhan } \\
\text { Batu. }\end{array}$ & $30 \mathrm{TBS}$ & $\begin{array}{l}\text { Polres Labuhan } \\
\text { Batu }\end{array}$ \\
\hline 5. & $\begin{array}{l}\text { Kanas Afdeling 5, Bilah Hulu, Labuhan } \\
\text { Batu. }\end{array}$ & $11 \mathrm{TBS}$ & $\begin{array}{l}\text { Polres Labuhan } \\
\text { Batu }\end{array}$ \\
\hline 6. & $\begin{array}{l}\text { Kebun Silau Dunia, Afdeling I, Damak } \\
\text { Urat, Sipispis, Sergei. }\end{array}$ & $\begin{array}{c}10 \mathrm{TBS} \\
(\text { Rp. } 600.000)\end{array}$ & Polres Sergei \\
\hline 7. & $\begin{array}{l}\text { Afdeling V Blok } 89 \text { TM 2004, Nagori } \\
\text { Banjar Ulu, Simalungun. }\end{array}$ & 3 sack & $\begin{array}{c}\text { Polsek Bosar } \\
\text { Maligas } \\
\end{array}$ \\
\hline 8. & $\begin{array}{l}\text { Afdeling } 3 \text { Kebun PTPN III Sei Putih, } \\
\text { Galang. }\end{array}$ & $17 \mathrm{TBS}$ & Polsek Galang \\
\hline 9. & $\begin{array}{l}\text { Tanah Raja di Apdeling V Blok 305, Desa } \\
\text { Leberia, Teluk Mengkudu, Sergei. }\end{array}$ & $\begin{array}{c}23 \text { TBS } \\
\text { (Rp. 550.000) }\end{array}$ & Polres Sergei \\
\hline
\end{tabular}

Fig. 2. Palm Theft in PTPN III (Source: PTPN III).

\begin{tabular}{|c|c|c|c|c|c|}
\hline No. & & Location & & Loss & Jurisdiction \\
\hline 1. & $\begin{array}{l}\text { Afdeling I } \\
\text { Marihat. }\end{array}$ & Blok 2010-A & Kebun & $45 \mathrm{TBS}$ & $\begin{array}{c}\text { Polres Pematang } \\
\text { Siantar }\end{array}$ \\
\hline
\end{tabular}




\begin{tabular}{|c|c|c|c|}
\hline 2. & $\begin{array}{l}\text { Afdeling VI Blok 05-S Kebun } \\
\text { Marihat. }\end{array}$ & 46 TBS & $\begin{array}{l}\text { Polres Pematang } \\
\text { Siantar }\end{array}$ \\
\hline 3. & $\begin{array}{l}\text { Afdeling I Blok 2010/Bt.4 Kebun } \\
\text { Marihat }\end{array}$ & $25 \mathrm{TBS}$ & $\begin{array}{l}\text { Polres Pematang } \\
\text { Siantar }\end{array}$ \\
\hline 4. & $\begin{array}{l}\text { Afdeling III Blok } 2011 \text { Ringin-Ringin } \\
\text { Kebun Marihat }\end{array}$ & $28 \mathrm{TBS}$ & $\begin{array}{l}\text { Polres Pematang } \\
\text { Siantar } \\
\end{array}$ \\
\hline 5. & $\begin{array}{l}\text { Areal Blok } 86 \text { UV Afdeling I, Meranti } \\
\text { Labuhan Batu }\end{array}$ & $14 \mathrm{TBS}$ & $\begin{array}{c}\text { Polres Labuhan } \\
\text { Batu } \\
\end{array}$ \\
\hline 6. & $\begin{array}{l}\text { Perkebunan Aek Kanopan, Labuhan } \\
\text { Batu Utara }\end{array}$ & 5 TBS & $\begin{array}{c}\text { Polres Labuhan } \\
\text { Batu Utara }\end{array}$ \\
\hline 7. & Afdeling Aek Nauli & $1 \mathrm{bunch} / 40 \mathrm{~kg}$ & Polsek Parapat \\
\hline 8. & $\begin{array}{l}\text { Padang Matinggi Nagori Teladan, } \\
\text { Bosar Maligas, Simalungun, }\end{array}$ & 6 sack & $\begin{array}{l}\text { Polsek Bosar } \\
\text { Maligas }\end{array}$ \\
\hline 9. & Bah Jambi Simalungun & $\begin{array}{c}2264 \text { TBS } \\
\text { (Rp. 15.634.330.000) } \\
\end{array}$ & $\begin{array}{c}\text { Polres } \\
\text { Simalungun } \\
\end{array}$ \\
\hline 10. & $\begin{array}{l}\text { Afdeling I, II, IV dan V (Kebun } \\
\text { Adolina), Batang Terap, Sergei. }\end{array}$ & $\begin{array}{c}5 \text { ton/day } \\
\text { (Rp. 652.963.905) } \\
\end{array}$ & Polres Sergei \\
\hline
\end{tabular}

Fig. 3. Palm Theft in PTPN IV (Source: PTPN IV).

The thieves come from community members who do not have permanent jobs, or work but lack income, including women [12], and women who act as middlemen [13]. Palm oil thieves also involve company insiders such as foremen, employees [14], watchmen, security units (security guards) so that the perpetrators are safe from stealing every day [15].

The foreman and his friends even threatened the garden security guard [16], so that they were free to go in and out for theft [17]. Also involved are local government officials [18], including employees who are protected by company management [19]. The perpetrator also threatened the garden assistant and even his family was also threatened by the thief [20].

\subsection{Factors Causing Palm Oil Theft in State-Owned Plantations}

The rise of cases of palm oil theft in state-owned plantations, in addition to economic factors, employment opportunities, is also inseparable from the tenuous relationship between the company's existence and the surrounding community and environment [21]. Repressive actions regardless of status and economy against the thieves actually widen the distance between the company and the surrounding community and in turn will increase the quantity of palm oil theft.

The company must find an alternative solution by involving the National Police in overcoming palm oil theft in Plantation SOEs by focusing on preventive actions through preemptive and preventive efforts.

\subsection{The Role of the Indonesian National Police in the Prevention of Palm Oil Theft}

Comparative studies aim to be congruent, not likely to equal the overall norm [22]. As the efforts to prevent crime in Japan are played by Koban and Chusaizho [23], while in Indonesia it is played by Babinkamtibmas to take pre-emptive action, and for preventive efforts carried out by Ditpamobvit and Sabhara [24]. 


\subsubsection{Babinkamtibmas Polri}

The role of the National Police, among others, is to create and maintain public security and order, including law enforcement, protection, protection, and community service [25]. The new paradigm of Polri is currently forming the Babinkamtibmas unit which is an important part of the concept of Community Policing (Polmas) which has been adopted from Japan since the issuance of the 2005 National Police Grand Strategy.

It is this Babinkamtibmas that can be expected as the frontline in carrying out pre-emptive efforts. The principle is to establish a partnership between the Police and the community to identify root causes, analyze, set priorities for action, evaluate the effectiveness of efforts to maintain public order and improve the quality of life of the community [26].

Babinkamtibmas uses the one village one Babinkamtibmas pattern. Its role is not to apply the law repressively to criminals, but how to minimize the crime rate through pre-emptive measures, so that repressive efforts against palm oil theft are expected to decrease. This is a manifestation of the National Police in creating and maintaining security, public order (kamtibmas), as well as protection, shelter, and community service.

Pre-emptive efforts include actively participating in shaping community skills, providing legal guidance and counseling to the community, human resource development, sports activities, mental education of citizens, establishing partnership forums such as the Police and Community Partnership Forum (FKPM) and the National Police and Community Partnership Center (BKPM), organize socio-cultural activities, monitor all developments in the village actively, conduct visits or visits, villages, patrols, socialize with the community, and others.

\subsubsection{Ditpamobvit, Korsabhara Baharkam Polri}

One of the national vital objects (Obvitnas) and certain objects that are included in the scope of duties and authorities of the Ditpamobvit, Korsabhara, and Baharkam Polri are BUMN. The provision of assistance services is carried out through pre-emptive and preventive actions with the principle of synergy between the Police and Plantation SOEs. The provision of security assistance is carried out based on a request from the Plantation BUMN [27].

If pre-emptive efforts are carried out far from the potential for criminality in the community, then preventive efforts are carried out in places that have the potential or are prone to possible factors for the occurrence of palm oil theft. Therefore, Babinkamtibmas, Ditpamobvit, and Korsabhara must be involved in efforts to prevent palm oil theft within Plantation SOEs.

An open pre-emptive effort is carried out to create security and order in the company environment by building coordination with the Obvitnas managers and certain objects as well as community members around the company's location and building partnerships with communities around the company.

The preventive efforts that are openly carried out are in the form of: regulating the traffic activities of people, goods, and vehicles in the company's environment; guarding the location to anticipate the occurrence of crime within the company; escort, supervision, an inspection of people, goods, documents, and vehicles entering/exiting the company.

Carry out patrols in the location, the environment around the company, both inside and outside the company environment by using a vehicle or on foot. Also, carry out permanent and incidental guarding by placing guard posts by the area of the object.

In addition, it also carries out covert efforts (intelligence) such as: detecting potential vulnerabilities that may occur both from within and from outside the company's environment; 
supervision of guests, employees, goods, and documents; as well as raising (cooperation) with employees and the community around the company.

\subsection{Optimization of Corporate Social Responsibility Funds for Plantation SOEs to Prevent Palm Oil Theft}

The main factor that has been an obstacle so far faced by the Police is the lack of operational costs to carry out all pre-emptive and preventive programs. As a result, the efforts made are only mediocre. Therefore, for the sake of the company itself, the community, the state, and for the public benefit, there is nothing wrong if the Plantation BUMN can allocate CSR funds to help carry out the pre-emptive and preventive tasks of the Police within the company.

The implementation of CSR in Romania concluded that there is a positive relationship between CSR and the value of the company reaching above 75\% [28]. Meanwhile, in Indonesia, CSR implementation is still low, below 50\% on average [29]. FFB theft in state-owned plantations is very massive and serious. Generally, the perpetrators are palm ninja around $10 \%$ to $15 \%$. In fact, it is the palm oil mafia that holds up to $85 \%$ of the proceeds of the theft, while $90 \%$ is organized crime [30].

It is the right solution if Babinkamtibmas, Ditpamobvit and Korsabhara are involved in early prevention, not for repressive measures like what was done by the Detectives. Efforts to combat palm oil theft so far have been through the role of the Detective Unit, by arresting and taking action as well as processing the law against the perpetrators of palm oil theft, it has not reduced the number of cases.

Meanwhile, for pre-emptive and preventive efforts, there is almost no cooperation between State-Owned Enterprises in Plantation and the Police. It should be understood that a crime if it only relies on repressive efforts will not always have a deterrent effect, but instead the crime will increase. It can be said that the phenomenon of palm oil theft in the Plantation BUMN environment is not something extraordinary because the efforts made so far are still mediocre.

The Internal Supervisory Unit (SPI) which is expected to be the task force and front guard in the State-Owned Enterprises in the Plantation Company to tackle fraud is also not effective [31]. In fact, there are still many cases of fraud that occur, not only theft, but also embezzlement, corruption, and others [32]. Corruption in BUMN has weakened GCG values and has an impact on state losses [33]. Prevention efforts are difficult for SPI, because it only focuses on monitoring and reporting to the Board of Directors on fraud that occurs [34].

Babinkamtibmas, Ditpamobvit, and Korsabhara have limited resources to enter the StateOwned Enterprises Plantation to make prevention efforts, but actually very effective in preventing palm oil theft through social approach efforts, guidance, counseling, guidance, information, and development, and various other activities to empower all the potential of the community to support the success of the goal of realizing security and order in the community around the company.

The reason for optimizing CSR funds in order to prevent the widespread theft of palm oil is not only to increase the company's economic income, but also because Plantation SOEs have social and environmental functions as mandated by Article 74 of the Limited Liability Company Law (UUPT) which mandates Social and Environmental Responsibility (TJSL) [35]. The regulation does not rule out the possibility of an allocation of CSR funds from the company to support the creation of security and public order in the Plantation BUMN environment.

Economic losses experienced by PTPN II, PTPN III, and PTPN IV as a result of rampant palm oil theft can in turn affect state losses. The social and environmental functions of the company will have an impact on the social and environmental development of the company in 
various fields, such as the construction of infrastructure for schools, roads, bridges, subsidies, scholarships, and others [36].

TJSL must be carried out by companies that carry out their business activities in the field and/or related to natural resources. TJSL can also be carried out by other companies even though their business activities are not engaged in natural resources. The regulations do not limit the criteria that companies must fund through CSR. This is based on the principle of fiduciary duty where the Board of Directors is the organ that is fully responsible for managing the company [37].

To implement CSR, it is based on the policy of the Board of Directors to take the attitudes and actions it deems necessary. How necessary or not CSR funds are channeled to prevent palm oil theft with the help of the Police to carry out various early prevention efforts against the rampant palm theft in the Plantation BUMN environment.

TJSL is implemented by the Board of Directors based on the company's annual work plan after obtaining approval from the Board of Commissioners or the General Meeting of Shareholders (GMS) by the Articles of Association (AD) unless otherwise stipulated in the laws and regulations. The company's annual work plan contains an activity plan and budget needed for the implementation of CSR.

Although the Board of Directors has full responsibility for taking the attitude and action of allocating CSR funds for the prevention of palm oil theft within the company, it must still obtain approval from the Board of Commissioners or the GMS. This effort is solely for early prevention and reducing the rate of palm oil theft which continues to increase and in turn, will have an impact on decreasing the value of palm fruit production.

As it is known that crime prevention efforts are an effective alternative solution to reduce crime rates. This method is the prevention of crime without the use of punishment (prevention without punishment). Of all the scopes of criminal policy, prevention is better than taking action because prevention will look at potential criminogenic factors through various social and environmental approaches [38], such as fostering public legal awareness [39].

A non-penal approach is needed to overcome various social and criminal problems or at least can reduce social problems and potential criminals so that they do not continue by looking at the root of the problem in society. To minimize the crime rate, it cannot only be done through the application of criminal law, but approaches other than criminal law such as social approaches, improving the community's economy, and others are actually more effective in reducing crime rates [40].

\section{Conclusions}

Efforts to prevent palm theft in state-owned plantations through optimizing CSR funds by involving the assistance of the National Police are very effective in reducing or at least reducing the rate of palm oil theft. This method, in turn, can add value to the production of palm fruit in state-owned plantations, increase corporate revenues and state revenues from state-owned plantations. So that the state's goal of establishing Plantation SOEs can be maximally achieved in the context of implementing public benefits such as fulfilling the lives of many people. It is hoped that the State-Owned Enterprises Plantation will form a partnership with the National Police by focusing on pre-emptive and preventive measures to prevent and reduce palm oil theft based on the mandate of Corporate Social Responsibility or Social and Environmental Responsibility in the Company Law. 


\section{Acknowledgments}

This research was partially support by our advisor and student of the doctoral program of law in University of North Sumatra.

\section{References}

[1] Pemerintah Republik Indonesia, Pasal 1 angka 1 UU No. 19 Tahun 2003 Tentang BUMN (UUBUMN) dan Pasal 1 angka 1 UU No. 40 Tahun 2007 Tentang Perseroan Terbatas (UUPT).

[2] Badan Usaha Milik Negara, "Statistik Jumlah BUMN." [Online]. Available: http://bumn.go.id/halaman/0-Statistik-Jumlah-BUMN.

[3] A. A. Chandra, "Asal-usul Pembentukan Holding BUMN," Detik Finance, 2017. [Online]. Available: https://finance.detik.com/berita-ekonomi-bisnis/d-3740436/asal-usul-pembentukanholding-bumn.

[4] P. De Cruz, Comparative law in a changing world. Routledge-Cavendish, 2008.

[5] J. Hennigfeld, M. Pohl, and N. Tolhurst, The ICCA handbook on corporate social responsibility. John Wiley \& Sons, 2006.

[6] Forum for Corporate Governance in Indonesia, "Seri Tata Kelola (Corporate Governance) Jilid II." 2001.

[7] B. Supriyono and S. Sjamsuddin, Antologi Administrasi Publik dan Pembangunan: Festschrift untuk Sjamsiar Sjamsuddin. Universitas Brawijaya Press, 2016.

[8] F. A. Widodo, "Peran Corporate Governance Perception Index serta Ukuran Perusahaan Terhadap Kinerja Keuangan Perusahaan Pada Hasil Survei The Indonesian Institute for Corporate Governance (IICG) Periode 2010-2012,” J. Akuntansi. Univ. Dian Nuswantoro Semarang, 2015.

[9] S. Suyono, "Perlindungan Hukum Terhadap Karyawan Dalam Rancangan Merger Diantara BUMN," Progr. Pascasarj. Univ. Sumatera Utara, Medan, 2003.

[10] J. Crowter, "Good Corporate Governance." Oxford Advanced Learners Dictionary, New York: Oxford University Press, 1995.

[11] B. H. Miraza, "Good Corporate Governance," Makal. disampaikan pada lokakarya Good Corpore Governance, kerjasama Progr. Pascasarj. Univ. Sumatera Utara, Progr. Pascasarj. Univ. Indones. Univ. South Carolina, Bursa Efek Jakarta dan Bapepam, Medan, 2000.

[12] Harian Batak Post, "Curi 2 Goni Berondolan Sawit PTPN II untuk Makan, Dua Ibu Nginap di Polres," Harian Batak Post, 2019. [Online]. Available: https://www.harianbatakpos.com/curi-2goni-berondolan-sawit-ptpn-ii-untuk-makan-dua-ibu-nginap-di-polres-langkat/.

[13] A. Lama, "Polda Sumut Tangkap 4 Perempuan Pencuri dan Penadah Tandan Buah Sawit Milik PTPN III," Tribun-Medan.com, 2018. [Online]. Available: https://medan.tribunnews.com/2018/07/07/polda-sumut-tangkap-4-perempuan-pencuri-danpenadah-tandan-buah-sawitmilik-ptpn-iii.

[14] Sumut24, "Direksi PTPN II Didesak Tindak Pencuri Libatkan Orang Dalam," Sumut24, 2019. [Online]. Available: https://www.sumut24.co/direksi-ptpn-ii-didesak-tindak-pencuri-libatkanorang-dalam.

[15] Buktipers.com, "Hancur, Perkebunan PTPN III 'Digerogoti' Centeng dan Maling," Buktipers.com, 2018. [Online]. Available: https://buktipers.com/hancur-perkebunan-ptpn-iiidigerogoti-centeng-dan-maling.

[16] Sugi, "Mandor DPO !!! Pelaku Pencurian Buah Kelapa Sawit Dan Dua Hansip PTPN III Tanah Raja di Ancam," Beritalima.com, 2016. [Online]. Available: https://beritalima.com/mandor-dpopelaku-pencurian-buah-kelapa-sawit-dan-dua-hansip-ptpn-iii-tanah-raja-ancam.

[17] Klik Today News, "Marak Pencurian TBS Kelapa Sawit di Kebun Marihat PTPN IV, Manajemen dan Fungsi Keamanan Layak Dievaluasi," Klik Today News, 2020. [Online]. Available: https://kliktodaynews.com/sumut/simalungun/marak-pencurian-tbs-kelapa-sawit-di-kebunmarihat-ptpn-iv-manajemen-dan-fungsi-keamanan-layak-dievaluasi. 
[18] Sumut Pos, "Pencurian Sawit Milik PTPN IV, Oknum Pejabat Sergai Terlibat," Sumut Pos, 2018. [Online]. Available: https://sumutpos.co/2018/12/17/pencurian-sawit-milik-ptpn-iv-oknumpejabat-sergai-terlibat.

[19] Lasser News Today, "Gawat..!! Manejemen Kebun Unit Gunung Bayu Diduga Melindungi Pelaku Penggelapan dan Pencurian Aset Produksi PTPN 4 Medan," Lasser News Today, 2018. [Online]. Available: http://www.lassernewstoday.com/berita/simalungun/gawat-manejemenkebun-unit-gunung-bayu-diduga-melindungi-pelaku-penggelapan-dan-pencurian-aset-produksiptpn-4-medan.

[20] Harian Batak Pos, "Pencurian Buah Sawit Semakin Ganas di PTPN 3 Kebun Aeknabara Selatan," Harian Batak Pos, 2019. [Online]. Available: https://www.harianbatakpos.com/pencurian-buahsawit-semakin-ganas-di-ptpn-3-kebun-aeknabara-selatan.

[21] S. Assembe-Mvondo, L. Putzel, and R. E. Atyi, Socioecological responsibility and Chinese overseas investments: The case of rubber plantation expansion in Cameroon, vol. 176. CIFOR, 2015.

[22] W. Menski, "Perbandingan hukum dalam konteks global sistem Eropa, Asia dan Afrika." Bandung: Nusa Media, 2016.

[23] S. Rahardjo, Membangun polisi sipil: Perspektif hukum, sosial, dan kemasyarakatan. Gramedia Pustaka Utama, 2007.

[24] T. Monica and J. H. Ahsan, Program Pemolisian Masyarakat. Jakarta: Institute for Defense Security and Peace Studies, 2009.

[25] Pemerintah Republik Indonesia, Undang-Undang Nomor 2 Tahun 2002 Tentang Kepolisian Republik Indonesia. 2002.

[26] Kepolisian Republik Indonesia, Peraturan Kepala Polri (Perkapolri) Nomor 7 Tahun 2008 Tentang Pedoman Dasar Strategi Dan Implementasi Pemolisian Masyarakat Dalam Penyelenggaraan Tugas Polri. 2008.

[27] Kepolisian Republik Indonesia, Peraturan Kepala Polri (Perkapolri) Nomor 13 Tahun 2017 Tentang Pemberian Bantuan Pengamanan Pada Objek Vital Nasional dan Objek Tertentu. 2017.

[28] S. C. Gherghina and G. Vintila, "Exploring the impact of corporate social responsibility policies on firm value: The case of listed companies in Romania," Econ. Sociol., vol. 9, no. 1, p. 23, 2016.

[29] T. K. Ridho, "The development of CSR implementation in Indonesia and its impact on company's financial and non-financial performance," KnE Soc. Sci., pp. 324-334, 2018.

[30] J. Junaedi, "Implementation of Good Corporate Governance (GCG) in the Field of Securing Plantation Assets," J. La Soc., vol. 1, no. 3, pp. 5-9, 2020.

[31] S. Syamsudin, I. Imronudin, S. T. Utomo, and A. N. Praswati, "Corporate Governance in Detecting Lack of Financial Report," JDM (Jurnal Din. Manajemen), vol. 8, no. 2, pp. 167-176, 2017.

[32] A. Siringo-Ringo, B. Nasution, N. N. Sirait, and M. Siregar, "The Importance of Transparency Principles in Management of State-Owned Plantation Enterprises," in International Conference on Law, Governance and Islamic Society (ICOLGIS 2019), 2020, pp. 29-33.

[33] Zulkipli, I. Aminuddin, H. Djafar, and S. Slamet, "Legal Policy of Corruption Eradication At State-Owned Enterprises Sector In Indonesia," Int. J. Sci. Technol. Res., vol. 5, no. 2, 2016

[34] Pemerintah Republik Indonesia, UU Nomor 19 Tahun 2003 Tentang BUMN. 2003.

[35] L. Karjoko, A. Sulitiyono, and I. G. A. K. R. Handayani, "Constructing Corporate Social Responsibility Base on Function Social Principles of Rights to Cultivate," Int. J. Business, Econ. Law, vol. 12, no. 2, pp. 550-551, 2017.

[36] R. E. Smith, Defining corporate social responsibility: A systems approach for socially responsible capitalism. Philadelphia: Program of Organizational Dynamics in the Graduate Division of the School of Arts and Sciences University of Pennsylvania, 2011.

[37] F. Harris, A. Jamaludin, and T. Anggoro, Hukum perseroan terbatas: Kewajiban pemberitahuan oleh direksi. Ghalia Indonesia, 2010.

[38] G. P. Hoefnagels, The other side of criminology: An inversion of the concept of crime. Springer Science \& Business Media, 2013.

[39] B. S. Fithri, "Pendekatan Integral Penal Policy dan Non Penal Policy dalam Penanggulangan 
Kejahatan Anak," Doktrina J. Law, vol. 1, no. 2, pp. 69-89, 2018.

[40] B. N. Arief, "Bunga Rampai Kebijakan Hukum Pidana Perkembangan Penyusunan Konsep KUHP Baru,” 2010. 